\title{
Expression of the CD6 T lymphocyte differentiation antigen in normal human brain
}

\author{
Barbara Mayer ${ }^{1}$, Ilona Funke ${ }^{1}$, Brian Seed ${ }^{2}$, Gert Riethmüller ${ }^{1}$ and Elisabeth Weiss ${ }^{1}$ \\ ${ }^{I}$ Institute for Immunology, University of Munich, D-8000 Munich, F.R.G., and ${ }^{2}$ Department of Molecular Biology, Massachusetts \\ General Hospital, Boston, MA 02114, U.S.A.
}

(Received 9 January 1990)

(Revised, received 29 March 1990)

(Accepted 25 April 1990)

Key words: Immunohistochemistry; Northern blot analysis; Lymphocyte differentiation antigen; Central nervous system antigen; Immunological cross-reactivity; Immune-neuroendocrine interaction

\section{Summary}

Antigens shared by the immune and central nervous systems (CNS) have been described repeatedly. The present study reports the expression of the CD6 lymphocyte differentiation antigen in normal human brain evidenced by immunohistochemistry and Northern blot analysis. A panel of various anti-CD6 monoclonal antibodies (mabs) tested on serial cryostat sections identified CD6-positive cells randomly scattered in parenchyma of all examined brain areas. Northern blot analysis with a highly sensitive cRNA probe revealed a $3.1 \mathrm{~kb}$ CD6-specific $\mathrm{mRNA}$ in various brain regions, especially in basalganglia and cortex cerebellum. Staining with mabs raised against different hematopoietic cell types, as well as hybridization with probes specific for the $\beta$ - and $\gamma$-T cell receptor (TCR) chains support the notion that CD6 is expressed by original brain cells. The nature of the CD6-positive cell type and possible functions of shared antigens in immune and nervous systems are discussed.

\section{Introduction}

Traditionally the central nervous system (CNS) has been considered an immunologically privileged site' (Barker and Billingham, 1988) anatomically and functionally separated from the immune system which itself was postulated to represent a

\footnotetext{
Address for correspondence: Barbara Mayer, Institute for Immunology, University of Munich, Goethestrasse 31, D-8000 Munich 2, F.R.G.

This work was supported by SFB 217 and the Genzentrum, München.
}

non-innervated tissue. For a few years, however, there is increasing evidence for the existence of an immune-neuroendocrine connection. Brain lesion studies in rodents showed that immunocompetent cells can be altered numerically and functionally by electrophysiological modifications (Hall et al., 1978; Katayama et al., 1981). On the other hand, an antigenic challenge can modify electrical and biochemical activities in brain neurons (Besedowsky et al., 1983a). Furthermore, the presence of noradrenergic and possible neuropeptidergic nerve fibers in human lymphoid tissues provides a morphological link between the two adaptive systems (Felten et al., 1985). 
In addition, leukocytes and brain cells have been shown to produce identical mediator substances. Similar to macrophages, astrocytes are able to synthesize $T$ cell stimulating factors such as interleukin-1 (IL-1), interleukin-6 (IL-6) and tumor necrosis factor- $\alpha$ (TNF- $\alpha$ ) (Fontana et al., 1984). Conversely, different human immunocompetent cells were found to release neuroendocrine messengers, such as vasoactive intestinal peptide (VIP), adrenocorticotropic hormone (ACTH), endorphin-like substances, histamine or serotonin (Cutz et al., 1978; Smith and Blalock, 1981; Besedowsky et al., 1983b). Numerous hormones and neurotransmitters have been demonstrated to stimulate or to depress immune response depending on the kind and dose of the modulator substance and the timing of its administration (e.g. O'Dorisio et al., 1985; Payan and Goetzl, 1985). The involvement of these messengers in immunoregulation requires their recognition by specific receptors on immune cells as reported for a great number of hormones and transmitters (Crabtree et al., 1980; Besedowsky et al., 1983b; Pert et al., 1985).

Besides these 'classical' receptors hematopoietic and brain cells share common antigenic determinants. Since the first demonstration of the Thy- 1 antigen expressed in the immune and nervous systems of the mouse (Reif and Allen, 1964) antigenic sharing in man has been described repeatedly (Garson et al., 1982; Hauser et al., 1983; Schuller-Petrovic et al., 1983; Budka and Majdic, 1985). At present the significance of the cross-reactivity between nervous elements and lymphocytes has not been clarified, but there is increasing evidence that shared antigens may be involved in the pathogenesis of immune-mediated neurologic diseases. For instance, the CD4-antigen found on hematopoietic and neural cells has been shown to bind the acquired immunodeficiency syndrome (AIDS) virus, causing both immunological and brain defects (Maddon et al., 1986; Funke et al., 1987). Furthermore, common antigens may be involved in system overlapping interactions. These considerations prompted us to search for the expression of various lymphocyte differentiation antigens in normal human brain and found positive staining with anti-CD6 reagents. In the present study we demonstrate the expression of the CD6 antigen in several brain regions investigated by double-staining technique (alkaline phosphatase anti-alkaline phosphatase (APAAP)-Nissl staining, double immunoenzymatic labeling) using different anti-CD6 monoclonal antibodies (mabs) and Northern blot analysis with a CD6-specific cRNA probe. CD6, previously designated $\mathrm{T} 12$, is a cell surface glycoprotein of approximately $100 \mathrm{kDa}$ and contains intra-chain disulfide bonds postulating a domain structure (Swack et al., 1988). It has been described as a late differentiation antigen on about $80 \%$ of mature $T$ lymphocytes, on a small subpopulation of normal $B$ cells and on the majority of B lymphocytic leukemia cells (Rieber et al., 1984). So far, neither the structure nor a definite physiological function of the CD6 antigen have been described.

\section{Materials and methods}

\section{Cell cultures and tissues}

Cell cultures. All human cell lines were received from the American Type Culture Collection (ATCC), Rockville, MD, U.S.A.. The glioma cell lines T98 G, U87 MG, U138 MG and 85 HG-59 were cultured in Eagle's minimum essential medium containing non-essential amino acids, sodium pyruvate and $10 \%$ heat-inactivated fetal calf serum (FCS) in the presence of $5 \% \mathrm{CO}_{2}$ at $37^{\circ} \mathrm{C}$, while $\mathrm{A} 172$ and $\mathrm{H} 4$ required Dulbecco's modified Eagle's medium with $4.5 \mathrm{~g} / 1$ glucose and $10 \%$ FCS. Single-cell suspensions of each monolayer culture were obtained by trypsinization $(0.25 \%)$ for $1 \mathrm{~min}$.

The human B lymphoma cell line Raji, which does not express the CD6 antigen, was grown in RPMI 1640 medium supplemented with 5\% FCS (all media and supplements from Gibco, Karlsruhe, F.R.G.). CD6-positive peripheral blood lymphocytes (PBLs) were isolated from heparinized blood of healthy donors by Ficoll-Hypaque (Pharmacia, Uppsala, Sweden) density gradient centrifugation according to the protocol of Boyum (1976). Cytospin preparations $\left(5 \times 10^{4}\right.$ cells per slide) were stored at $-80^{\circ} \mathrm{C}$ until use for staining.

Tissues. The specimens of different human brain areas obtained $5-6 \mathrm{~h}$ post-mortem were 

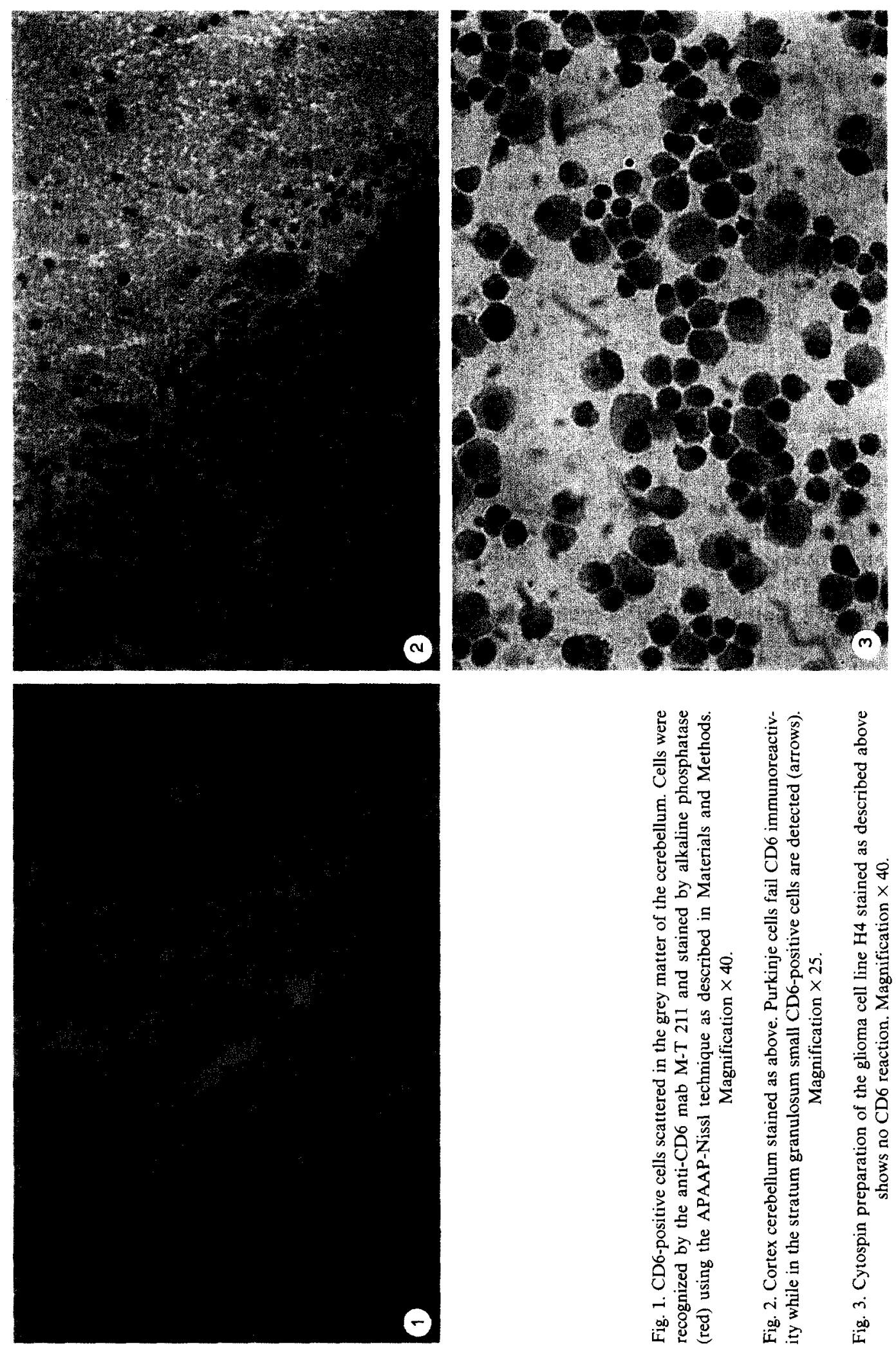

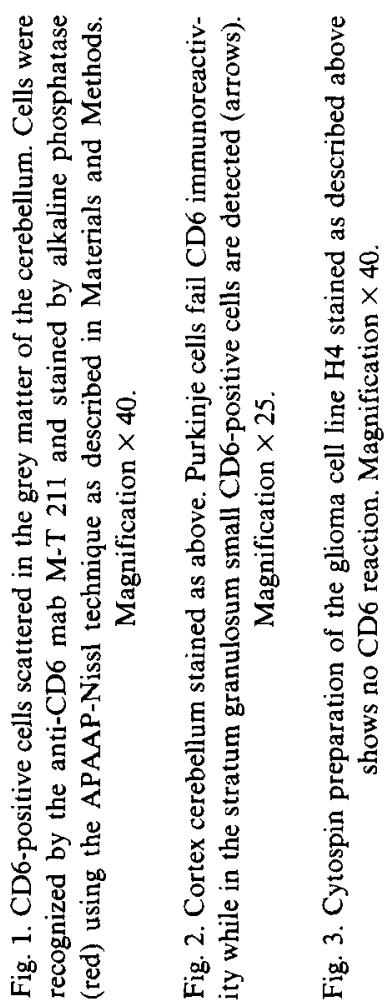


snap frozen in liquid nitrogen and stored at $-80^{\circ} \mathrm{C}$ (kindly provided through Dr. Müller, Department of Psychiatry, University of Munich, Munich, F.R.G.). Brain tissue showed neither by macroscopy nor by light microscopy any neuropathologic abnormalities. Control material including CD6-positive lymphoid organs (tonsil, thymus) and CD6-negative tissues (kidney, liver) was obtained 20-30 min after surgical excision and was handled in the same way. For immunohistochemistry serial cryostat sections $(15 \mu \mathrm{m})$ were prepared on $100 \mu \mathrm{g} / \mathrm{ml}$ poly-L-lysine (Sigma, Deisenhofen, F.R.G.)-coated slides and stored at $-80^{\circ} \mathrm{C}$.

\section{Monoclonal antibodies}

All primary mabs were used in appropriate concentrations (ranging from $1: 50$ to $1: 1000$ ) diluted in Tris-buffered saline (TBS) pH 7.6 containing $1 \%$ human serum.

CD6 antigen was identified with a panel of ten different anti-CD6 mabs recognizing closely related epitopes (Knapp et al., 1990). Further staining was performed with a monocyte marker (M-M 42), a common leukocyte marker (anti-LC), with mabs directed against different TCR chains (BMA 031, Identity-T TCR delta 1) and in addition with an astrocyte-specific antibody (anti-glial fibrillary acidic protein (GFAP)), an anti-human macrophage marker (EBM 11) and an anti-galactocerebroside antibody (anti-GC).

Staining specificity was controlled by replacing the first antibody (a) with TBS buffer and (b) with an anti-CD8 mab (M-T811) of the same immunoglobulin subclass. Sections without primary mab or with $\mathrm{CD} 8$ as primary mab were always negative. A major histocompatibility complex (MHC) class I mab (W6/32) was employed as positive control for the staining procedure. On brain sections only blood vessel endothelium, connective tissue structures and occasional unidentified cells were W6/32 positive, while neurons did not stain for MHC class I. The mabs used for immunohistochemical studies are summarized in Table 1.

\section{Immunohistochemistry}

APAAP-Nissl staining. Before immunostaining, cytospins and sections were thawed at room temperature, then fixed in acetone $\left(-20^{\circ} \mathrm{C}\right)$ and subsequently in chloroform for $10 \mathrm{~min}$. After preincubation with human serum (diluted $1: 10$ in TBS) for $30 \mathrm{~min}$, primary mabs were applied in predetermined dilutions. The APAAP-staining procedure yielding a red reaction product was carried out as described by Mason (1985). After washing in TBS a second fixation step with $10 \%$ formaldehyde for $10 \mathrm{~min}$ was performed before staining the slides with $0.5 \%$ cresyl violet solution (pH 3.9, $37^{\circ} \mathrm{C}, 30 \mathrm{~min}$ ).

Double immunoenzymatic labeling. In the two-enzyme approach the acetone-fixed tissue sections were labeled first with the non-conjugated primary mab (anti-LC, anti-GFAP, EBM 11) in an appropriate dilution for $60 \mathrm{~min}$. After incubation with the second antibody (peroxidase-conjugated rabbit anti-mouse $\operatorname{IgG}$ and $\operatorname{IgM}$ ) unspecific binding sites were blocked with $2 \%$ mouse serum for $30 \mathrm{~min}$. Subsequently the biotin-labeled anti-CD6 mab (T 152) was applied for $1 \mathrm{~h}$, followed by an alkaline phosphatase-conjugated streptavidin complex for $30 \mathrm{~min}$. The immunoperoxidase sandwich was developed with 3 amino-9-ethylcarbazole (AEC) and $\mathrm{H}_{2} \mathrm{O}_{2}$ for 8 min, yielding a red reaction product, while the biotin-streptavidin system was visualized by a naphthol AS-MX phosphate/Fast Blue BB salt solution for $20 \mathrm{~min}$, yielding a blue reaction product.

\section{Preparation of the CD6 CRNA for Northern blot analysis \\ The CD6-cDNA clone 13.3 was a kind gift of} Dr. B. Seed, General Hospital of Massachusetts, Boston, MA, U.S.A. The identity of the insert coding for the CD6 antigen was tested by transient transfection of the cDNA in $\cos 7$ cells and precipitation with appropriate mabs (kindly carried out by Dr. J. Johnson, Institute of Immunology, University of Munich, Munich, F.R.G., 1988, unpublished data). The restriction map of the clone was established according to standard protocols (Maniatis et al., 1982) by cleaving the plasmid DNA with appropriate restriction endonucleases under conditions recommended by the manufacturer (Boehringer, Mannheim, F.R.G.). Digestion patterns were analyzed on a $1 \%$ agarose gel. The CD6 cRNA probe was prepared by in vitro transcription. Briefly, the $1.5 \mathrm{~kb}$ EcoRI fragment of 
the CD6 cDNA was subcloned into the EcoRI-restricted transcription vector pT3T7 lac (Boehringer). The DNA construct was linearized with the enzymes $B g l$ II (T3 RNA polymerase reaction) and BamHI (T7 RNA polymerase reaction), respectively, and the in vitro transcription assay was performed as described by Melton and Krieg (1984). After purification and size determination on a $5 \%$ acrylamide- $8.3 \mathrm{M}$ urea gel the transcription reactions were tested for sense and antisense strand by Northern blot analysis. The antisense CD6 cRNA (T3 RNA polymerase reaction) was used for hybridization of the blot with the brain RNA samples.

\section{RNA isolation and Northern blot hybridization}

Total RNA was extracted from snap-frozen samples using the guanidinium isothiocyanate method (Chirgwin et al., 1979). 20-25 $\mu \mathrm{g}$ of total RNA was electrophoresed through a $1.2 \%$ agarose-formaldehyde gel (Maniatis et al., 1982) and transferred to Hybond-N membrane (Amersham, Buchler, Braunschweig, F.R.G.). The filter was prehybridized at $58^{\circ} \mathrm{C}$ in $50 \%$ deionized formamide, $1 \mathrm{M} \mathrm{NaCl}, 50 \mathrm{mM}$ Tris $\mathrm{HCl} \mathrm{pH} 7.5,1 \%$ sodium dodecyl sulfate (SDS), 10\% Denhardt's, $250 \mu \mathrm{g} / \mathrm{ml}$ Escherichia coli RNA and $100 \mu \mathrm{g} / \mathrm{ml}$ denatured salmon sperm DNA for at least $7 \mathrm{~h}$. Subsequently the blot was incubated overnight in the same mixture additionally containing $10 \mathrm{ng} / \mathrm{ml}$

${ }^{32}$ P-labeled antisense CD6 cRNA. Control hybridizations consecutively were performed on a duplicate filter with a TCR $\gamma$, a TCR $\beta$ and a $\beta$-actin cDNA probe using the same hybridization protocol. Previous hybridization signals were removed by washing the filters in $0.1 \times \mathrm{SSC}, 1 \%$ SDS at $68^{\circ} \mathrm{C}$ for $30 \mathrm{~min}$.

\section{Results}

Detection of the CD6 antigen by immunohistochemistry

Using all available anti-CD6 mabs, with the combined APAAP-Nissl staining, we observed a consistent staining pattern on the four tested brain specimens and the various glioma cell lines.

TABLE 1

MONOCLONAL ANTIBODIES USED FOR IMMUNOHISTOCHEMICAL STUDIES IN NORMAL HUMAN BRAIN

\begin{tabular}{llll}
\hline $\begin{array}{l}\text { Monoclonal } \\
\text { antibody }\end{array}$ & Isotype & Specificity & Source \\
\hline M-T 211 & IgG1 & CD6 & Rieber, E.P., Munich, F.R.G. \\
M-T 411 & IgG1 & CD6 & Rieber, E.P., Munich, F.R.G. \\
M-T 421 & IgG1 & CD6 & Rieber, E.P., Munich, F.R.G. \\
T 146 & IgG1 & CD6 & Rieber, E.P., Munich, F.R.G. \\
T 147 & IgG1 & CD6 & Rieber, E.P., Munich, F.R.G. \\
T 148 & IgG1 & CD6 & Rieber, E.P., Munich, F.R.G. \\
T 149 & IgG1 & CD6 & Rieber, E.P., Munich, F.R.G. \\
T 150 & IgG1 & CD6 & Rieber, E.P., Munich, F.R.G. \\
T 151 & IgG1 & CD6 & Rieber, E.P., Munich, F.R.G. \\
T 152 & IgG1 & CD6 & Rieber, E.P., Munich, F.R.G. \\
M-T 811 & IgG1 & CD8 & Rieber, E.P., Munich, F.R.G. \\
M-M 42 & IgM & CD14 & Rieber, E.P., Munich, F.R.G. \\
Anti-LC & IgG1 & CD45 & Dako, Hamburg, F.R.G. \\
W6/32 & IgG2a & MHC class I & ATCC, Rockville, MD, U.S.A. \\
BMA 031 & IgG2b & TCR $\alpha, \beta$ & Behring, Marburg, F.R.G. \\
Identity-T TCR delta 1 & IgG1 & TCR 8 & Biermann, Bad Nauheim, F.R.G. \\
Anti-GFAP & IgG1 & GFAP & Dako, Hamburg, F.R.G. \\
EBM 11 & IgG1 & Microglia & Dako, Hamburg, F.R.G. \\
Anti-GC & IgG2a & Galacto cerebroside & Sigma, Deisenhofen, F.R.G. \\
\hline
\end{tabular}




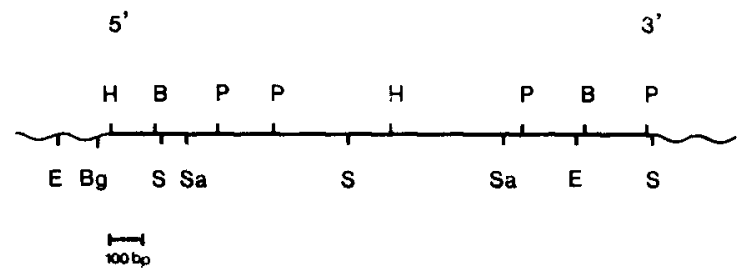

Fig. 4. Restriction map of the CD6 cDNA clone 13.3. B: Bst XI, Bg: BglII, E: EcoRI, H: HindII, P: PstI, S: Sau3A, Sa: SacI, vector CDM8.

Anti-CD6 immunoreactive cells were found in the grey matter of all examined brain areas (cerebellum, pons, basal ganglia, thalamus, corpus amygdaloideum, lobi cerebri), of which basal ganglia and cortex cerebelli showed a distinct in-
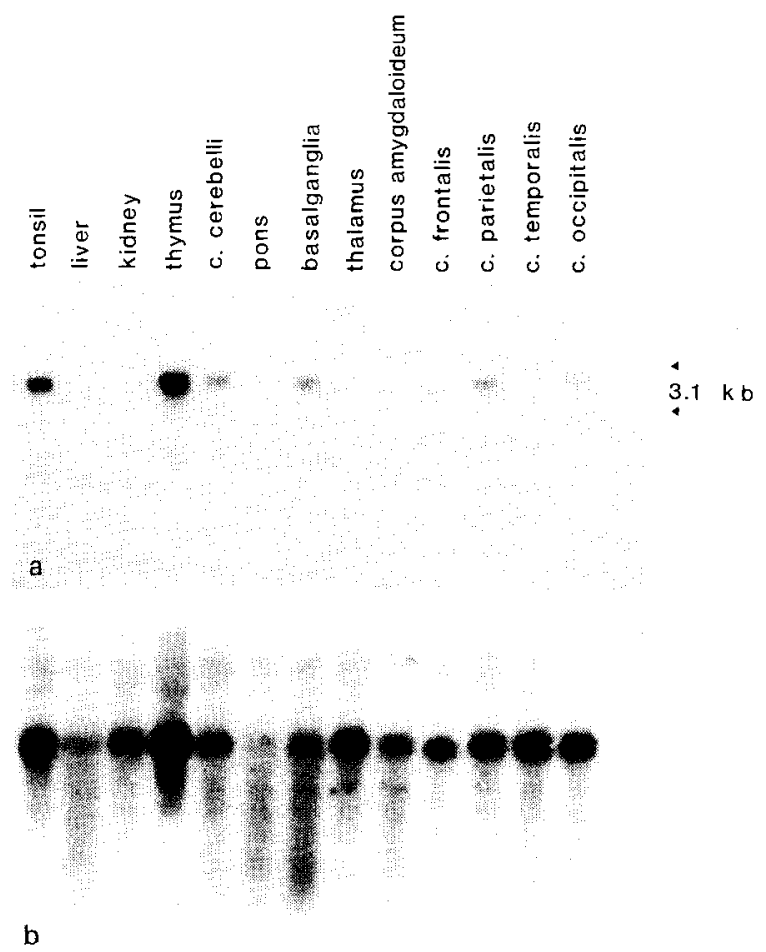

Fig. 5. Expression of CD6 mRNA in brain and various control tissues. $20-25 \mu \mathrm{g}$ of total RNA was separated on a $1.2 \%$ agarose-formaldehyde gel and transferred to Hybond- $\mathrm{N}$ membrane. (a) Hybridization with a ${ }^{32}$ P-labeled CD6-specific cRNA (1.5 kb) reveals a $3.1 \mathrm{~kb}$ CD6 mRNA in positive control tissues (tonsil, thymus) and various brain regions. (b) Hybridization with a ${ }^{32}$ P-labeled $\beta$-actin cDNA probe $(1.7 \mathrm{~kb})$ was used as control for the amount of total RNA applied in each lane. Arrows mark the $18 \mathrm{~S}$ and $28 \mathrm{~S}$ rRNA. crease of stained cells. CD6-positive cells were not only located in some small vessels and capillaries. but could also be detected randomly scattered in brain parenchyma (up to $20 \mathrm{CD} 6$-reactive cells per section). As depicted in Fig. 1 these CD6-positive cells, morphologically characterized by a small cell body (about $10 \mu \mathrm{m}$ ), showed a staining pattern consistent with a cytoplasmic and/or cell surface antigen localization.

Neither pyramidal neurons nor Purkinje cells showed any CD6-positive reaction (Fig. 2). In view of the apparent CD6-negative staining of glial cells in brain, we examined six different
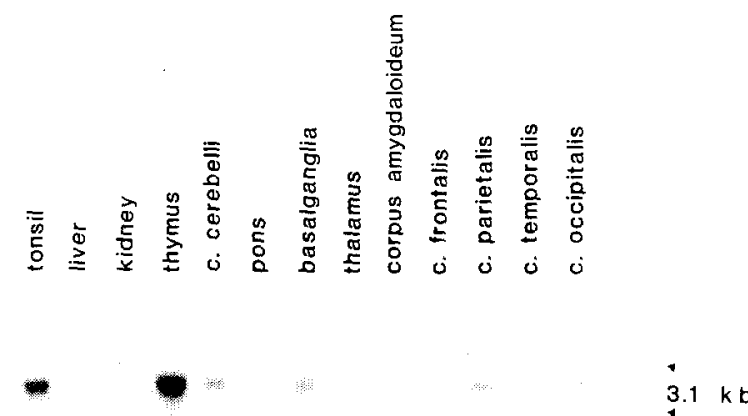

a
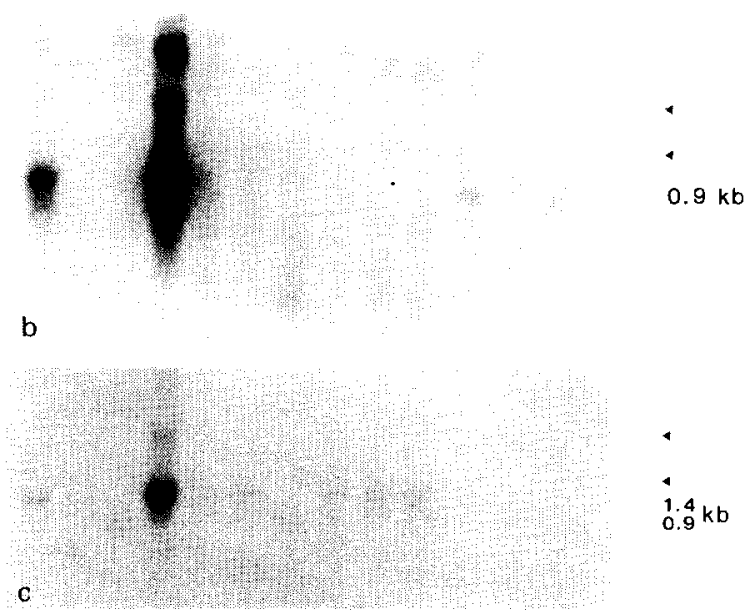

Fig. 6. (a) See legend to Fig. 5a. (b) Hybridization with a ${ }^{32} \mathrm{P}$-labeled TCR $\beta$ probe $(1.0 \mathrm{~kb})$ performed as described above demonstrates only a truncated $0.9 \mathrm{~kb}$ transcript in cortex parietalis and cortex occipitalis. (c) Hybridization with a ${ }^{32} \mathrm{P}$ labeled TCR $\gamma$ probe $(0.7 \mathrm{~kb})$ reveals a $1.4 \mathrm{~kb}$ full-length transcript in tonsil, thymus, pons, thalamus, corpus amygdaloideum and cortex frontalis while kidney and basal ganglia contain a shortened $0.9 \mathrm{~kb}$ transcript. Arrows mark the $18 \mathrm{~S}$ and $28 \mathrm{~S}$ rRNA. 


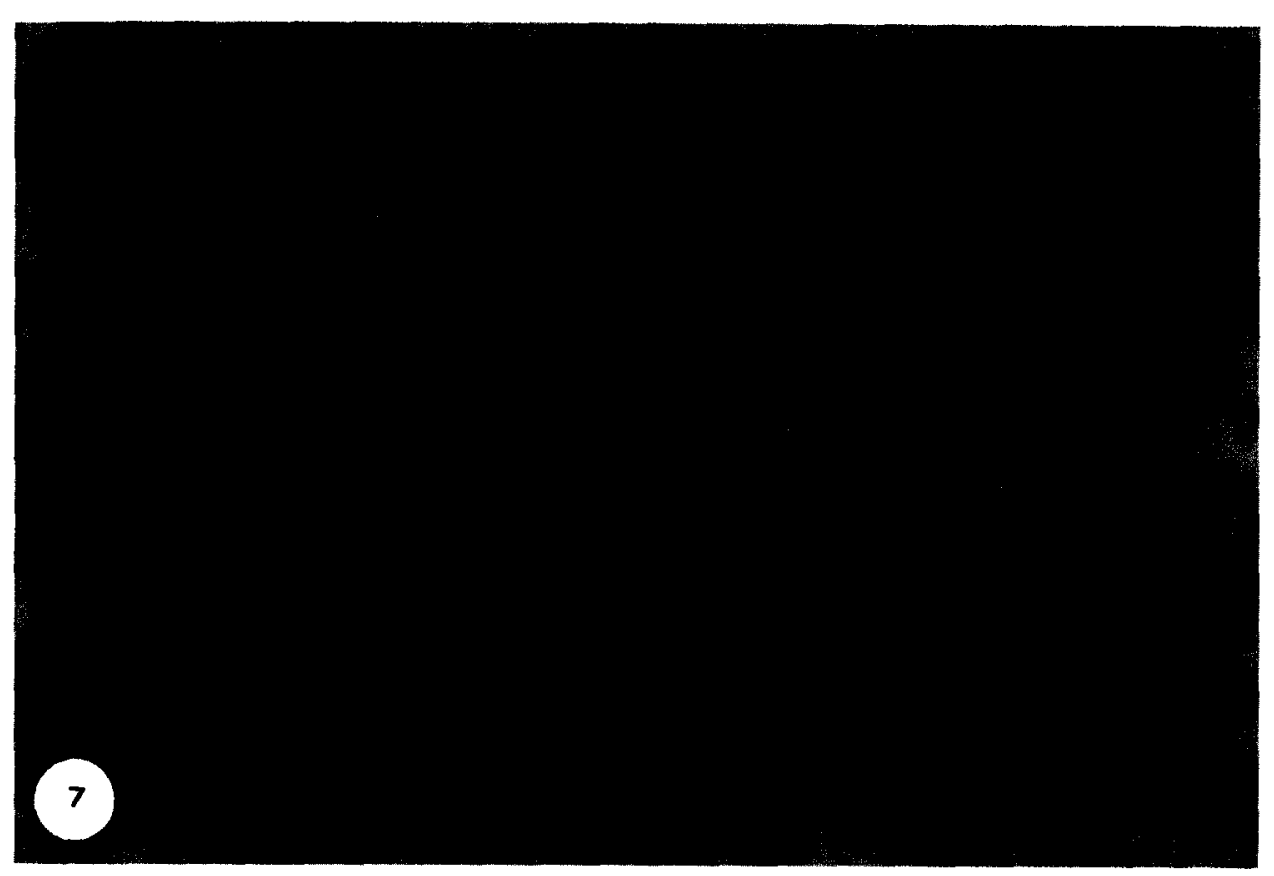

Fig. 7. Cortex cerebellum stained with anti-human macrophage mab EMB 11 using the APAAP technique. Several EBM 11-positive cells are detected in the stratum granulosum with the typical morphology of microglia. Magnification $\times 25$.

glioma cell lines and none of them showed any CD6 expression (Fig. 3). Tonsil, thymus and PBLs, however, revealed a strong reaction pattern corre- sponding with the known distribution of ' $\mathrm{T}$ cells while on kidney and liver sections only a few hematopoietic cells were CD6-immunoreactive.

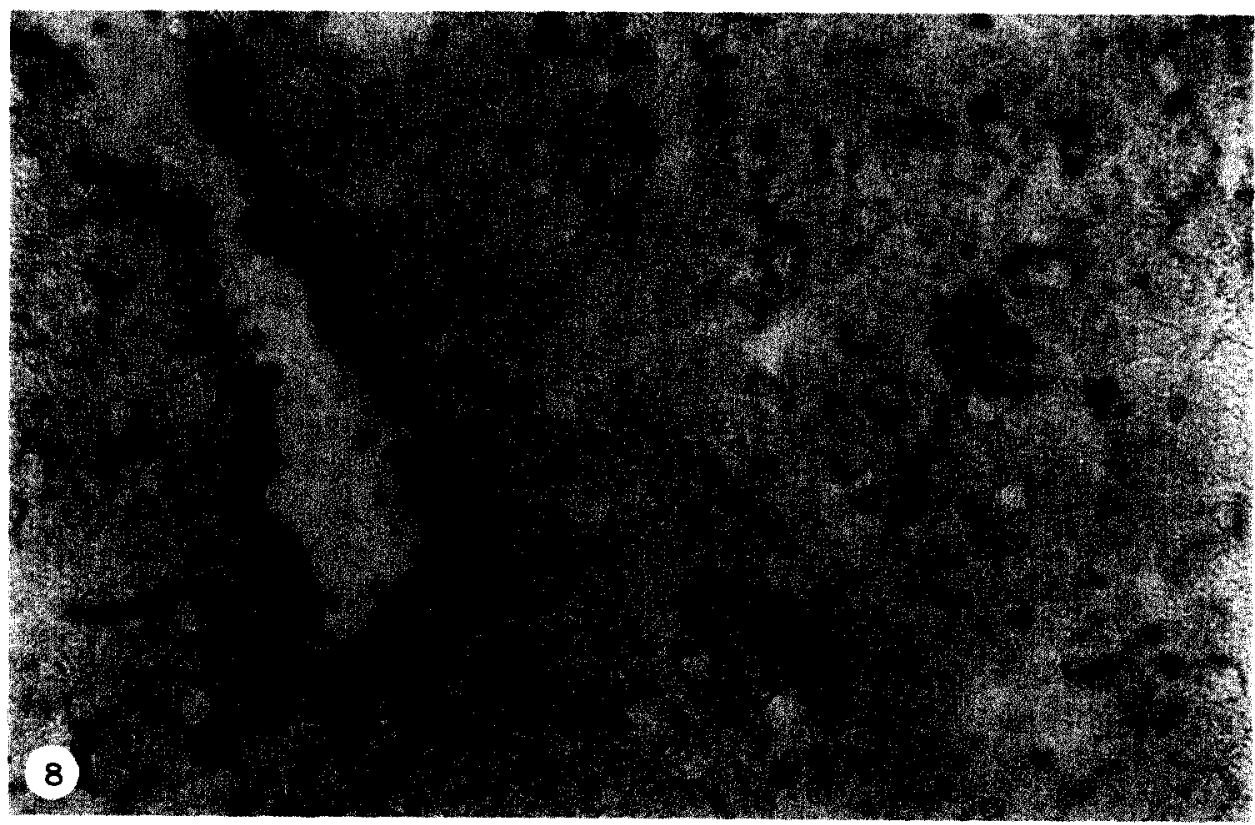

Fig. 8. Double immunoenzymatic labeling with anti-LC stained by peroxidase (red) and a biotin-conjugated T152, stained by alkaline phosphatase (blue) as described in Materials and Methods. In the area of the basal ganglia a CD6-positive cell (arrow) is present next to a CD45-positive capillary. Magnification $\times 40$. 
The Raji B lymphoma cell line used as negative control was CD6-negative.

On serial brain sections anti-GFAP, anti-GC and the anti-microglia marker EBM 11 resulted in a staining pattern quite different from patterns obtained with anti-CD6 (Fig. 7). In addition the failure of the small CD6-positive cells to stain with anti-CD45 in the double staining experiments exclude them to be lymphocytes (Fig. 8).

Furthermore, in various brain areas, especially in pons and cortex frontalis, staining with an mab directed against the delta chain of the $T$ cell receptor (TCR) indicated more positive cells than with an anti- $\alpha \beta$-TCR mab. Incubation with the isotype-matched control mab M-T 811 yielded a complete lack of staining on the examined brain sections. Thus, the $\mathrm{T}$ lymphocytes in normal human brain detected with anti-TCR reagents apparently do not express the CD8 $\mathrm{T}$ cell differentiation molecule and are characterized in their majority by the $\gamma \delta$-TCR complex.

\section{Detection of the CD6 expression by Northern blot analysis}

To confirm the immunohistochemical staining results, total RNA was extracted from the same human brain areas and the various tested control tissues. Because of the few CD6-positive cells scattered in brain parenchyma only a weak hybridization signal could be expected. Therefore Northern blot analysis was performed using a CD6-specific antisense cRNA probe in order to increase hybridization efficiency (Cox et al., 1984).

For preparation of the cRNA a restriction map of the CD6 cDNA clone 13.3 was constructed (Fig. 4). Subsequently the EcoRI fragment was subcloned in the vector pT3T7 lac. Employing antisense strand of the transcription reaction as probe for Northern blot analysis we detected a 3.1 kb CD6 mRNA in cerebellum, basal ganglia, cortex parietalis and cortex occipitalis. Thus, the CD6-specific message in brain is of the same size as the CD6 mRNA in the tested lymphoid tissues (Fig. $5 a$ ). In a comparative analysis using a human $\beta$-actin cDNA probe as standard we found basal ganglia to exhibit the strongest CD6 mRNA hybridization signal followed by cerebellum and cortex cerebri areas (Fig. $5 b$ ).
Control hybridizations with probes specific for the different TCR heterodimers do not correlate with the CD6 mRNA signal and thus make it unlikely that the detected CD6 mRNA found in brain is expressed by $T$ lymphocytes (Fig. 6). In accordance with staining results Northern blot analysis with the TCR $\gamma$ cDNA probe showed a 1.4 $\mathrm{kb}$ functional transcript in pons, thalamus, corpus amygdaloideum and cortex frontalis (Fig. 6c), while hybridization with the TCR $\beta$ CDNA only revealed a shortened $(0.9 \mathrm{~kb})$, non-functional message in cortex parietalis and cortex occipitalis (Fig. $6 b)$.

\section{Discussion}

The present study provides direct evidence that CD6 expression is not exclusively restricted to cells of hematopoietic origin but is also found in normal human brain parenchyma.

Staining with several mabs directed against different hematopoietic cell types on serial sections excluded the infiltration of CD6-positive blood cells in brain tissue and a distribution pattern distinct from that obtained with anti-CD6 mabs was observed. Various reagents directed against lymphocyte antigens were used but failed to stain the small CD6-positive cells. In double staining experiments with the anti-lymphocyte marker anti-LC, the CD6-positive cells in brain parenchyma showed no CD45 reactivity and were also negative for staining with additional anti-CD reagents (CD1a, b, c, CD8 and CD14). Rare $T$ lymphocytes were detected using anti-TCR reagents which were distinct from the CD6-positive cells. These findings were confirmed by Northern blot analysis employing a TCR $\beta$ and a TCR $\gamma$ probe, respectively.

For further characterization of the CD6-positive cells in brain parenchyma anti-CD6 labeling was compared with anti-GFAP staining showing no coincidence. Microglia as source for the CD6reactive cells was excluded by staining with EBM 11. Neither the morphology nor the frequency of EBM 11-positive cells agree with the CD6-staining pattern (see Fig. 7). Similar results were obtained with the anti-oligodendrocyte marker anti-GC. In addition none of the tested glial cell lines provided 
any CD6-positive reaction. These results agree with previous immunoperoxidase studies reporting a lack of anti-T12 staining in the white matter of human brain (Hauser et al., 1983). Furthermore the prominent motor neurons (Purkinje cells, pyramidal neurons) failed any CD6 immunoreactivity ascertained with the combined APAAP-Nissl staining.

Because of their anatomical localization and their morphology the CD6-positive cells in brain parenchyma can be discussed as a small neuronal cell type. Additional neuroanatomical studies such as electron microscopy analyses are required to establish definitively the nature of the CD6-reactive cells in brain.

In contrast to the APAAP-Nissl staining, CD6 mRNA could not be demonstrated in all examined brain areas. The paucity of CD6-reactive cells present in CNS ( 7 in 100 cells) may explain the difference between immunohistochemical and Northern blot results.

Besides the fact that RNA might be lost during preparation, hybridization even using a cRNA probe is not sensitive enough to detect the smallest amounts of the CD6 message. The stronger hybridization signals in the mRNA of some brain areas might indicate that these regions contain more CD6-positive cells. Indeed in basal ganglia and cerebellum more CD6-stained cells were detected correlating with a relative strong CD6 mRNA signal.

The functional role of lymphocyte differentiation antigens expressed by neural cells is still unknown. As the function of the CD6 molecule on $\mathrm{B}$ and $\mathrm{T}$ lymphocytes is not known so far, the role of CD6 on brain cells is even more puzzling. Perhaps the few CD6-positive cells scattered in normal CNS tissue may represent cells in a 'be prepared' condition confirming the increasing evidence for the immunocompetence of the CNS. Possibly brain cells can be induced to express CD6 antigen in response to an immunological stimulus as shown for MHC class II and intercellular adhesion molecule 1 (ICAM-1) (Massa and ter Meulen, 1987; Frohmann et al., 1989). Up to now only the stimulating effect of different antiCD6 mabs on mature $\mathrm{T}$ cells has been shown (Rieber et al., 1986; Swack et al., 1988).

Furthermore antigenic sharing may provide a molecular explication for abnormalities in immune and central nervous systems based on an immunological attack against a common antigen or conversely a more positive aspect: coexpressed antigens may be involved in the cellular interactions and the reciprocal functional modulation between the two systems to accomplish the abundance of information derived from the internal and external environment and to maintain a stable state of the organism.

\section{Acknowledgements}

The authors are greatly indebted to Dr. N. Müller, Department of Psychiatry, University of Munich, Munich, F.R.G. for providing human brain tissue and Dr. B. Seed, General Hospital of Massachusetts, Boston, MA, U.S.A., for the CD6 cDNA clone 13.3. We also thank our colleagues Dr. J. Johnson and J. Lehmann for molecular biology assistance and Dr. E.P. Rieber for the contribution of the anti-CD6 mabs.

\section{References}

Barker, C.F. and Billingha, R.E. (1977) Immunologically privileged sites. Adv. Immunol. 25, 1-10.

Besedowsky, H.O., del Rey, A.E., Sorkin, E., Da Prada, M., Burri, R. and Honegger, C. (1983a) The immune response evokes changes in brain noradrenergic neurons. Science 221, 564-565.

Besedowsky, H.O., del Rey, A.E. and Sorkin, E. (1983b) What do the immune system and the brain know about each other? Immunol. Today 4, 342-346.

Boyum, A. (1976) Isolation of lymphocytes, granulocytes and macrophages. Scand. J. Immunol. 5 (Suppl. 5), 9-15.

Budka, H. and Majdic, O. (1985) Shared antigenic determinants between human hemapoietic cells and nervous tissues and tumors. Acta Neuropathol. 67, 58-66.

Chirgwin, J.J., Przbyla, A.E., MacDonald, R.J. and Rutter, W.J. (1979) Isolation of biologically active ribonucleic acid from sources enriched in ribonuclease. Biochemistry 18 , 5294-5299.

Cox, K.H., Deleon, D.V., Angerer, L.M. and Angerer, R.C. (1984) Detection of mRNAs in sea urchin embryos by in situ hybridization using asymmetric RNA probes. Dev. Biol. 101, 485-502.

Crabtree, G.R., Munck, A. and Smith, K.A. (1980) Glucocorticoids and lymphocytes. J. Immunol. 124, 2430-2435.

Cutz, E., Chan, W., Track, N.S., Goth, A. and Said, S. (1978) Release of vasoactive intestinal polypeptide in mast cells by histamine liberators. Nature 275, 661-662. 
Felten, D.L., Felten, S.Y., Carlson, S.L., Olschowka, J.A. and Livnat, S. (1985) Noradrenergic and peptidergic innervation of lymphoid tissue. J. Immunol. 135, 775s-765s.

Fontana, A., Heugartner, H., de Tribolet, N. and Weber, E. (1984) Glioblastoma cells release interleukin-1 and factors inhibiting interleukin-2-mediated effects. J. Immunol. 132, 1837-1844.

Frohmann, E.M., Frohmann, T.C., Dustin, M.L., Vayuvegula, B., Choi, B., Gupta, A., van den Noort, S. and Gubta, S. (1989) The induction of intercellular adhesion molecule 1 (ICAM-1) expression on human fetal astrocytes by interferon- $\gamma$, tumor necrosis factor $\alpha$, lymphotoxin, and interleukin-1; relevance to intracerebral antigen presentation. J. Neuroimmunol. 23, 117-124.

Funke, I., Hahn, A., Rieber, E.P., Weiss, E. and Riethmüller, G. (1987) The cellular receptor (CD4) of the human immunodeficiency virus is expressed on neurons and glia cells in human brain. J. Exp. Med. 165, 1230-1235.

Garson, J.A., Beverly, P.C.L., Coakham, H.B. and Harper, E.J. (1982) Monoclonal antibodies against human T-lymphocytes label Purkinje neurons of many species. Nature 298, 375-377.

Hall, N.R., Lewis, J.K. and Schimpf, R.D. (1978) Effects of diencephalic and brainstem lesions on hemapoietic stem cells. Soc. Neurosci. 4, 20 (abstract).

Hauser, S.L., Bhan, A.K., Gilles, F.H., Hoban, C.J., Reinherz, E.L., Schlossmann, S.F. and Weiner, H.L. (1983) Immunohistochemical staining of human brain with monoclonal antibodies that identify lymphocytes, monocytes and Ia antigen. J. Neuroimmunol. 5, 197-205.

Katayama, M., Kobayashi, S., Kuramoto, N. and Yokoyama, M.M. (1981) Effects of hypothalamic lesions on lymphocyte subsets in mice. Ann. N.Y. Acad. Sci. 496, 366-376.

Knapp, W., Dörken, B., Rieber, P., Stein, H., Gilks, W.R., Schmidt, R.E. and van dem Borne, A.E.G.Kr. (Eds.) (1990) Leukocyte Typing IV, Oxford University Press, Oxford New York - Tokyo (in press).

Maddon, P.J., Dalgleish, A.G., McDougal, J.S., Clapham, P.R., Weiss, R.A. and Axel, R. (1986) The T4 gene encodes the AIDS virus receptor and is expressed in the immune system and the brain. Cell 47, 333-348.

Maniatis, T., Fritsch, E.F. and Sambrook, J. (1982) Molecular Cloning: A Laboratory Manual, Cold Spring Harbor Laboratory, Cold Spring Harbor, NY.

Mason, D.Y. (1985) Immunocytochemical labeling of monoclonal antibodies by the APAAP immunoalkaline phosphatase technique. In: G.R. Bullock and P. Petrusz (Eds.),
Techniques in Immunohistochemistry, Academic Press, New York, pp. 25-40.

Massa, P.T. and Ter Meulen, V. (1987) Analysis of Ia induction on Lewis rat astrocytes in vitro by virus particles and bacterial adjuvants. J. Neuroimmunol. 13, 259-271.

Melten, D.A. and Krieg, P.A. (1984) Efficient in vitro synthesis of biologically active RNA and RNA hybridization probes from plasmids containing a bacteriophage SP9 promoter. Nucleic Acids Res. 12, 7035-7070.

O'Dorisio, M.S., Wood, C.L. and O'Dorisio, T.M. (1985) Vasoactive intestinal peptide and neuropeptide modulation of the immune response. J. Immunol. 135, 792s-796s.

Payan, D.G. and Goetzl, E.J. (1985) Modulation of lymphocyte function by sensory neuropeptides. J. Immunol. 135, $783 \mathrm{~s}-786 \mathrm{~s}$.

Pert, C.B., Ruff, M.R., Weber, R.J. and Herkenham, M. (1985) Neuropeptides and their receptors: a psychosomatic network. J. Immunol. 135, 820s-826s.

Reif, A.E. and Allen, J.M.V. (1964) The AKR thymic antigen and its distribution in leukemias and nervous tissues. $J$. Exp. Med. 120, 413-435.

Rieber, P., Lohmeyer, J., Schendel, D.J., Göttlinger, H., Brodmann, S., Rank, G., Heydecke, S., Kopp, E. and Riethmüller, G. (1984) Characterization of functional human $\mathrm{T}$ cell subsets by monoclonal antibodies. In: $\mathrm{A}$. Bernard, L. Boumsell, J. Dausset, C. Milstein and S.F. Schlossmann (Eds.), Leukocyte Typing, Springer Verlag, Berlin - Heidelberg - New York - Tokyo, pp. 303-311.

Rieber, P., Rank, G., Wirth, S., Wilhelm, M., Kopp, E. and Riethmüller, G. (1986) Modulation of T cell functions by monoclonal 'pan T cell' antibodies not directed against the T cell receptor complex. In: E.L. Reinherz, B.F. Haynes, L.M. Nadler and J.P. Bernstein (Eds.), Leukocyte Typing II, Springer Verlag, Berlin - Heidelberg - New York Tokyo, pp. 233-242.

Schuller-Petrovic, S., Gebhart, W., Lassmann, H., Rumpolt, H. and Kraft, D. (1983) A shared antigenic determinant between natural killer cells and nervous tissue. Nature 305 , 179-181.

Smith, E.M. and Blalock, J.E. (1981) Human lymphocyte production of ACTH and endorphine-like substances: association with leukocyte interferon. Proc. Natl, Acad. Sci. U.S.A. $78,7530-7534$.

Swack, J.A., Gangemi, R.M.R., Rudd, C.E. and Romain, P.L. (1988) CD6 is a phosphorylated glycoprotein involved in $\mathrm{T}$ cell activation. FASEB J, 2, 7884 (abstract). 